\title{
Prevalence, characteristics, and impact of pain during the postpartum period
}

\author{
Prevalência, características e impacto da dor no período pós-parto \\ Prevalencia, características y repercusión del dolor en el período de posparto
}

How to cite this article:

Brito APA, Caldeira CF, Salvetti MG. Prevalence, characteristics, and impact of pain during the postpartum period. Rev Esc Enferm USP. 2021;55:e03691. doi: https://doi.org/10.1590/S1980-220X2019023303691

\author{
Ana Paula Almeida Brito ${ }^{1}$ \\ Caroline Fernandes Caldeira ${ }^{2}$ \\ Marina de Góes Salvetti ${ }^{3}$ \\ 1 Universidade de São Paulo, Escola de \\ Enfermagem, Programa de Pós-Graduação \\ em Enfermagem, São Paulo, SP, Brazil. \\ 2 Secretaria de Estado da Saúde, Instituto \\ de Saúde, São Paulo, SP, Brazil. \\ ${ }^{3}$ Universidade de São Paulo, Escola de \\ Enfermagem, Departamento de Enfermagem \\ Médico Cirúrgica, São Paulo, SP, Brazil.
}

\begin{abstract}
Objective: To identify the prevalence of pain in puerperal women, describe the characteristics of pain and its impacts on the performance of daily life activities, and evaluate satisfaction with received analgesia. Method: Cross-sectional study which included women who had given birth. These were evaluated within 72 hours postpartum in a public teaching hospital in São Paulo city. Obstetric and clinical data were evaluated, as well as presence and characteristics of pain and its impact on daily activities. Results: A total 128 women participated in this study. The prevalence of pain was $36.7 \%$ during the interview and $54.6 \%$ in the previous 24 hours. The main pain site was the abdominal region $(64.7 \%)$ and pain intensity was moderate to $48.9 \%$ of women, with intermittent frequency in $58 \%$ of the cases. There was a significant association between presence of pain and type of delivery (cesarean; $\mathrm{p}=0.030$ ). Not being able to provide care to the newborn, requiring going to a different unit, increased pain perception $(p=0.038)$. A significant impact of pain on the capacity of walking, eating, sleeping, taking care of the baby, evacuating, breathing deeply, breastfeeding, and sitting was verified. Conclusion: Pain was frequent during the postpartum period and significantly affected the mothers' activities, indicating a need for improving pain management in puerperium.
\end{abstract}

DESCRIPTORS

Pain; Postpartum Period; Obstetric Nursing; Maternal-Child Nursing.
Corresponding author:

Marina de Góes Salvetti

Escola de Enfermagem da

Universidade de São Paulo

Rua Dr. Enéas de Carvalho Aguiar,

419, Cerqueira César

CEP 05403-000 - São Paulo, SP, Brazil

mgsalvetti@usp.br
Received: 08/15/2019

Approved: 09/22/2020 


\section{INTRODUCTION}

Pain is a distressing experience associated to actual or potential tissue damage with sensitive, emotional, cognitive, and social components ${ }^{(1)}$. The postpartum period is unique for each woman and pain may make recovery, self-care, and care of the newborn more difficult, while being also a risk factor for depression ${ }^{(2-6)}$.

Perineal trauma is frequent during vaginal delivery and may be spontaneous or provoked by perineum incisions ${ }^{(7)}$. Perineal pain, caused by spontaneous laceration or episiotomy, may affect up to $65 \%$ of women after vaginal delivery ${ }^{(8)}$. Perineal discomfort may continue for up to two weeks after childbirth for circa $20 \%$ of women, for three months for $10 \%$ of women, and up to one year after birth for $6 \%$ of women ${ }^{(8)}$. Thus, care of the perineum and pain management in the postpartum period are fundamental ${ }^{(9)}$.

Many women choose cesarean birth due to fear of perineal laceration and pain related to normal birth ${ }^{(10-11)}$. Nonetheless, cesarean birth involves risks, which are present in all surgical procedures, and is associated to pain in the post-operative period. In the presence of pain, contact with the baby and resumption of routine activities may be hindered ${ }^{(10-11)}$.

Breastfeeding can also be affected by pain, either due to women's situation in postpartum, breast trauma or other events affecting this are $\mathrm{a}^{(12)}$. The pain related to breastfeeding is a sensorial and affective experience which is unpleasant for women and may lead to breastfeeding interruption ${ }^{(13)}$.

In all the described situations, nurses have a fundamental role in evaluating and alleviating pain during puerperium. Pain management and prevention of complications are essential to facilitate women's recovery, contributing to their return to daily activities. In this sense, understanding the prevalence and impact of pain on daily activities of hospitalized puerperal women is essential to propose better strategies for its control, qualifying care.

The objectives of the present study were thus to identify the prevalence of pain in puerperal women, describing the characteristics and impact of pain on daily life activities and evaluating satisfaction with the received analgesia.

\section{METHOD}

\section{Study Design}

Cross-sectional study.

\section{SCENARIO}

This study was developed in the Rooming-in (RI) unit of a middle-sized public teaching hospital in São Paulo city which provides secondary care and has 153 beds. The RI has 28 beds for puerperal women and four beds for gynecological surgery. This RI unit has a mean of 200 childbirths every month, with a minimum hospitalization time of 60 hours independently of type of delivery.

This study is part of a larger project, named "Prevalence of pain and analgesic adequacy in University Hospital: diagnosis study", and is focused exclusively on pain in women in the postpartum period.

\section{Population}

The study population comprised women who were 18 or older and gave birth by any type of delivery.

\section{SeleCtION CRITERIA}

The selection criteria for study participation were being 18 or older, being hospitalized in the RI unit within 72 hours after childbirth and accepting participation.

The convenience sample comprised 128 puerperal women hospitalized in the RI unit in the study period within 72 hours after birth who accepted to participate. There were no exclusions or refusals.

\section{Data collection}

Data collection was performed by an undergraduate researcher student once a week between September 2017 and February 2018. Puerperal women were interviewed by their beds, after a mean 46 hours from childbirth.

The questionnaire developed for this study comprised clinical data, obstetric data, presence of pain, pain characteristics (intensity according to the Verbal Numeric Pain Scale, site, and frequency), impact of pain on daily activities (sitting, walking, eating, sleeping, brushing teeth, evacuating, moving on the bed, combing hair, breathing deeply/ coughing, feeding the baby, and caring for the baby), and pain reevaluation after one to two hours.

The variables for characterization of puerperal women included: age, number of pregnancies, abortions, previous childbirths, and the type of delivery conducted during hospitalization. The pain characterization variables included its presence/absence in the moment of the interview and in the previous 24 hours, intensity, frequency, localization (main and secondary), and impact on daily activities.

Women who presented pain during the interview were asked whether they would like to receive analgesic medication in accordance with medical prescription. If the answer were positive, the researcher would ask the unit's nurse to administer the medication and reevaluate the pain one hour after, asking about their satisfaction with the relief and whether a new intervention would be necessary.

\section{Data ANALysis AND treatment}

The statistical analysis was assisted by the Statistical Package for the Social Sciences (SPSS), version 22.0. The prevalence of pain was calculated, and inferential and descriptive statistics were used. After verifying normality, Chi-squared, T test, Wilcoxon, and Mann-Whitney tests were used, depending on the type of the analyzed variable, to verify the association of pain with obstetric variables. To verify the impact of pain on daily life activities, a linear regression model was employed. The significance level, or $\mathrm{p}$-value, adopted for all analyses was $<0.05$.

\section{ETHICAL ASPECTS}

All puerperal women hospitalized in the RI within 48 hours after childbirth received information on the study objectives and were invited to participate. Those who accepted 
participation signed the Informed Consent Form (ICF) in two copies (one was kept by the patient and the other, by the researcher) and answered, by their beds, to the questionnaire developed specifically for this study.

This research was approved by the institution's Research Ethics Committee in Opinion. 1.596.360/2016, in compliance with resolution n. 466/2012, by the National Health Council.

\section{RESULTS}

Participants included 128 women. The age of puerperal women participating in this research ranged from 18 to 41 , with a mean of 26.5 years $(\mathrm{SD}=6.3)$. Most of them $(59.3 \%)$ were aged 20 to 29 . Concerning the number of pregnancies, $46 \%$ were primigravidae and $40.6 \%$ were primiparous. Regarding type of delivery, $58.6 \%$ had vaginal birth and $43.4 \%$ had cesarean birth. Comorbidities included gestational diabetes, diabetes mellitus, asthma, treated syphilis, migraine, gastritis, hypothyroidism, borderline disorder, chemical dependency, systemic arterial hypertension, and anemia.

The prevalence of pain during the interview was $36.7 \%$ and $54.6 \%$, when the 24 hours before the interview are considered. Mean pain intensity was 5.6 and the pain was moderate or intense for $86 \%$ of women (Figure 1), with intermittent frequency in most cases (58\%). Forty puerperal women reported no type of pain after childbirth.

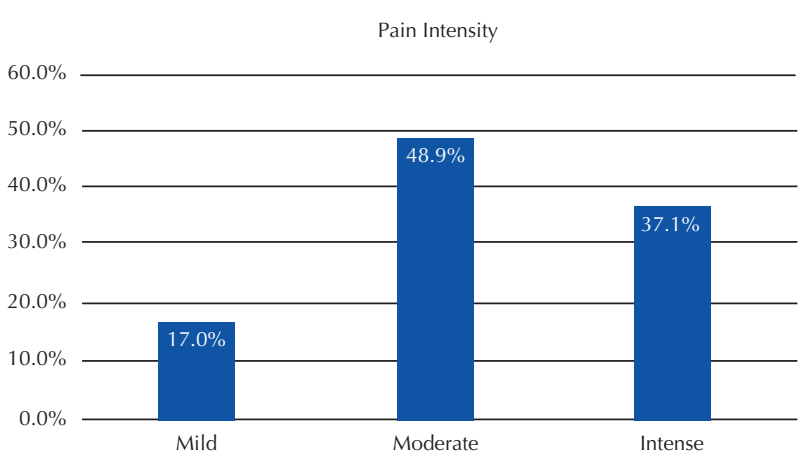

Figure 1 - Distribution of pain intensity as per numeric pain scale among women who reported pain in the previous 24 hours - São Paulo, SP, Brazil, 2018.
Regarding pain site, a higher frequency was observed for the abdominal region $(64.7 \%)$, followed by the perineal and genital region (35.8\%), according to Table 1.

Bivariate analysis shows that the presence of pain in the previous 24 hours was associated to cesarean birth and to the fact that the newborn was hospitalized in a different unit, i.e., in the Intermediate Care Neonatal Unit (Unidade de Cuidados Intermediários Neonatal - UCIN) or the Neonatal Intensive Care Unit (Unidade de Terapia Intensiva Neonatal - UTINEO). Age, number of pregnancies, and presence of perineal trauma presented no association with the presence of pain (Table 2).

The possible relations between pain intensity, type of delivery, and type of anesthesia were also explored. However, an association between pain and type of delivery $(\mathrm{p}=0.220)$ or type of anesthesia $(\mathrm{p}=0.499)$ was not observed (Table 3$)$.

Table 1 - Distribution of primary and secondary pain sites - São Paulo, SP, Brazil, 2018.

\begin{tabular}{lll}
\hline Variables & N & $\%$ \\
\hline Primary pain site $(\mathbf{n}=\mathbf{8 8})$ & 57 & \\
Abdominal & 15 & 64.7 \\
Perineal and genital & 6 & 17.0 \\
Dorsal (above the waistline) & 4 & 6.8 \\
Breast & 2 & 4.6 \\
Head & 2 & 2.3 \\
Pelvic & 1 & 2.3 \\
Cervical & 1 & 1.1 \\
UL* & 1 & 1.1 \\
\hline Secondary pain site (n =14) & 5 & 7.1 \\
Perineal and genital & 3 & 35.8 \\
Abdominal & 2 & 21.4 \\
Nipples & 2 & 14.3 \\
Dorsal (above the waistline) & 14.3 \\
Lumbar (below the waistline) & & 7.1 \\
LL* & 5 & \\
\hline
\end{tabular}

*UL - Upper limbs **LL - Lower limbs

Table 2 - Association of pain and maternal and childbirth characteristics - São Paulo, SP, Brazil, 2018.

\begin{tabular}{|c|c|c|c|c|c|}
\hline Variables & $\begin{array}{c}\text { Total sample } \\
\text { n (\%) }\end{array}$ & Current pain (\%) & p-value & $\begin{array}{c}\text { Pain in } 24 \text { hours } \\
(\%)\end{array}$ & p-value \\
\hline Mother's age (years) & & & 0.571 & & 0.338 \\
\hline$<20$ & 16 (12.5) & 10.6 & & 10.0 & \\
\hline $20 \vdash 25$ & 39 (30.4) & 31.9 & & 30.0 & \\
\hline $25 \vdash-30$ & 37 (28.9) & 23.4 & & 28.6 & \\
\hline $30 \vdash-35$ & 18 (14.0) & 19.2 & & 14.3 & \\
\hline$\geq 35$ & $18(14.0)$ & 14.9 & & 17.1 & \\
\hline Pregnancies & & & 0.793 & & 0.298 \\
\hline Primigravida & $59(46)$ & 39.0 & & 55.9 & \\
\hline Multigravida & $69(54)$ & 34.8 & & 53.6 & \\
\hline Parity & & & 0.927 & & 0.627 \\
\hline Primiparous & $52(40.6)$ & 36.5 & & 57.7 & \\
\hline Multiparous & $76(59.4)$ & 37.3 & & 53.3 & \\
\hline
\end{tabular}




\begin{tabular}{|c|c|c|c|c|c|}
\hline Variables & $\begin{array}{c}\text { Total sample } \\
\text { n (\%) }\end{array}$ & Current pain (\%) & p-value & $\begin{array}{c}\text { Pain in } 24 \text { hours } \\
(\%)\end{array}$ & p-value \\
\hline NB in $\mathbf{R} \mathbf{I}^{* *}$ & & & 0.209 & & 0.038 \\
\hline No & $14(10.9)$ & 57.1 & & 71.4 & \\
\hline Yes & $114(89.0)$ & 34.2 & & 52.6 & \\
\hline Type of delivery & & & 0.567 & & 0.030 \\
\hline Cesarean & $53(41.4)$ & 39.6 & & 66.0 & \\
\hline Vaginal*** & $75(58.6)$ & 34.7 & & 46.7 & \\
\hline Perineal trauma & & & 0.395 & & 0.455 \\
\hline Intact & $30(40.0)$ & 29.0 & & 38.2 & \\
\hline RD1\# & $15(20.0)$ & 26.7 & & 53.3 & \\
\hline RD2\#\#/Episiotomy & $30(40.0)$ & 43.3 & & 53.3 & \\
\hline
\end{tabular}

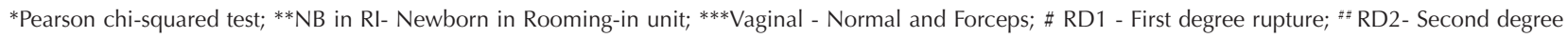
rupture.

Table 3 - Association of pain intensity with type of delivery and type of anesthesia - São Paulo, SP, Brazil, 2018.

\begin{tabular}{lcccc}
\hline & \multicolumn{4}{c}{ Pain intensity } \\
\cline { 2 - 5 } & $\mathbf{n}(\%)$ & $\begin{array}{c}\text { Mean } \\
\left(\text { SD }^{\#}\right)\end{array}$ & Median & p-value* \\
\hline Type of delivery & & & & 0.220 \\
& & & & \\
Cesarean & $41(46.5)$ & $5.8(2.3)$ & 6.0 & 0.499 \\
Vaginal & $47(53.5)$ & $5.3(1.9)$ & 5.0 & \\
\hline Type of anesthesia & & & & \\
& & & & \\
None & $17(19.4)$ & $5.8(1.4)$ & 5.5 & 5.0 \\
Subarachnoid & $51(57.9)$ & $5.6(2.3)$ & 5.0 & \\
Local & $20(22.7)$ & $5.0(1.7)$ & & \\
\hline
\end{tabular}

"Standard Deviation; ${ }^{*} \mathrm{~T}$ test

Regarding the impact of pain on daily activities, it was verified to significantly affect the capacity of sitting, walking, eating, moving on the bed, sleeping, breathing deeply/ coughing, feeding the baby, evacuating, and caring for the baby (Table 4).

Table 4 - Analysis of the impact of pain on daily activities - São Paulo, SP, Brazil, 2018.

\begin{tabular}{lccc}
\hline Variables & OR\# & Cl 95\% & P-value* \\
\hline Sitting & 1.56 & $1.35-1.85$ & $<\mathbf{0 . 0 0 1}$ \\
Walking & 1.48 & $1.29-1.75$ & $<\mathbf{0 . 0 0 1}$ \\
Eating & 1.43 & $1.14-1.90$ & $\mathbf{0 . 0 0 2}$ \\
Moving on the Bed & 1.40 & $1.23-1.63$ & $\mathbf{< 0 . 0 0 1}$ \\
Breathing deeply & 1.40 & $1.22-1.63$ & $<\mathbf{0 . 0 0 1}$ \\
Evacuating & 1.39 & $1.17-1.72$ & $\mathbf{< 0 . 0 0 1}$ \\
Breastfeeding the baby & 1.33 & $1.16-1.57$ & $<\mathbf{0 . 0 0 1}$ \\
Caring for the baby & 1.29 & $1.13-1.51$ & $<\mathbf{0 . 0 0 1}$ \\
Sleeping & 1.26 & $1.10-1.48$ & $\mathbf{0 . 0 0 1}$ \\
Brushing teeth & 1.26 & $0.96-1.75$ & 0.097 \\
Combing hair & 1.14 & $0.91-1.47$ & 0.256 \\
\hline
\end{tabular}

"Odds Ratio; *Linear Regression Model
Among women who reported pain during the interview, $31.9 \%$ requested medication for the pain, were medicated, and then revaluated one hour later. During pain reevaluation, all women reported being satisfied with the pain relief and did not deem necessary a new intervention, although the pain had not been eliminated in all cases.

\section{DISCUSSION}

The experience of pain is subjective and affects quality of life negatively. According to the Brazilian Society for the Study of Pain (Sociedade Brasileira para Estudo da Dor), the perception of pain varies from one individual to another and is influenced by culture and previous experience ${ }^{(14)}$.

In this study, $54.6 \%$ of puerperal women reported pain in the previous 24 hours, a prevalence inferior to that found in a study which analyzed pain related to childbirth and found a prevalence of pain of $72.9 \%$ in the previous 24 hours $^{(15)}$.

This research's results show that pain was significantly more common among mothers who had their newborn hospitalized in other units (nursery or neonatal ICU) and needed to move to follow their children, which may be related to this higher mobility or to the emotional overload of having their newborn in a different unit. Studies indicate that the process of mother-baby separation due to prematurity or newborn complications in the immediate postpartum period makes the mother feel fear, anxiety, insecurity, and distress ${ }^{(16-17)}$, emotions which may negatively influence the perception of pain. In these situations, nurses should act as facilitators of skin-to-skin contact as soon as possible, fostering the bond between mother and baby ${ }^{(16)}$.

A systematic review which analyzed the RI system versus separate care has shown that the exclusive breastfeeding rate in the fourth day after childbirth was significantly higher for the RI group, 86\%, when compared with the separate care group, which presented $45 \%$ of exclusive breastfeeding ${ }^{(18)}$. The skin-to-skin contact between mother and baby, like breastfeeding, triggers oxytocin release, which increases the sensation of pleasure and reduces peripheral nervous sensitivity ${ }^{(11)}$. 
In this study, pain was significantly more frequent among women who had cesarean birth; however, pain intensity presented no association with type of delivery, as seen in another Brazilian study, which compared the pain intensity in women who had normal birth and women who had caesarean birth and also found no significant difference for pain intensity ${ }^{(15)}$. The literature shows that women submitted to cesarean section reported 2.4 times more pain compared to women who had vaginal delivery ${ }^{(19)}$. After abdominal incision, inflammatory peptides, lipids, and mediators, such as histamine, bradykinin, prostaglandin, serotonin, and substance $\mathrm{P}$ are released, activating primary afferent nociceptors, which transmit the pain information and promote the perception of pain ${ }^{(20)}$.

In cesarean birth, abdominal discomfort is added to disturbance from surgical incision, which makes mobility more difficult and entails other problems, such as lower limb edema and cervical and lumbar pain ${ }^{(2)}$.

Abdominal pain was the most frequent $(64.7 \%)$ in this study, followed by perineal and genital pain (38.4\%). Abdominal pain in puerperium may be associated to surgical incision in the case of cesarean section, which may also be related to breastfeeding, since there is oxytocin release and an increase in uterine tonus, leading to an increase in abdominal colic ${ }^{(2)}$.

Regarding pain intensity, $48.9 \%$ of women reported moderate pain, with a mean 5.6 as per Verbal Numeric Pain Scale. In the literature, the pain intensity in the puerperium was similar to that found by this study, with means of 5.2 and 5.5 , respectively ${ }^{(10-11)}$.

The linear regression analysis has shown a significant impact of pain on daily activities, including the capacity of walking, eating, sleeping, caring for the newborn, evacuating, sitting on the bed, and breathing deeply.

A study evaluating 86 women in the immediate postpartum (vaginal and cesarean) for physical discomfort and difficulties in conducting functional activities has shown that pain restrained the activities of sitting and standing up, walking, lying down, and bathing ${ }^{(2)}$. Such study states that inappropriate pain management in the postpartum period negatively affects the process of recovery and increases the risk of complications ${ }^{(2)}$.

The physical and emotional demands of caring for a newborn are amplified in the presence of pain. It is thus fundamental that nurses and other health professionals seek efficient pain management, contributing to the process of recovery and to the efficient performance of the mother role ${ }^{(11)}$.

In this study, only pharmacological interventions were used for pain management, following the routine of HU-USP (University Hospital). Nurses, however, may use multiple non-pharmacological interventions for controlling pain in puerperium, such as massage, acupuncture, relaxation techniques, physical methods, such as heat and cold, among others ${ }^{(21)}$.

A systematic review evaluating non-pharmacological therapies in postpartum has shown that Transcutaneous Electrical Nerve Stimulation (TENS) and cryotherapy produced a significant reduction in abdominal and perineal pain in the postpartum period; the data for the techniques of acupuncture and auriculotherapy, on the other hand, were inconclusive ${ }^{(22)}$.

This study has shown that $17 \%$ of women presented perineal pain, a finding similar to that of a Swedish study which evaluated 461 primiparous women and observed that $10 \%$ of them faced problems of perineal pain after childbirth. Considering these data, it is essential to investigate and recognize the impact of perineal pain on the daily life of women and in their psychological and emotional well-being in the postpartum ${ }^{(23)}$.

Studies show that applying ice to the perineum for 15 and 20 minutes relieves pain, leading to numbness and anesthesia in this area ${ }^{(24-25)}$. A systematic review which included 10 randomized clinical trials, involving 1,825 women, found evidence to support the efficiency of local treatment with application of cold. When applied to the perineum from 24 to 72 hours after birth, this approach was efficient to relieve pain, in comparison with no treatment or treatment with hot bath ${ }^{(25)}$.

Another systematic review, including 15 randomized clinical trials which involved 2,131 puerperal women, has shown that aromatherapy can be applied as a non-invasive, complementary intervention to promote physical and psychological comfort in women during postpartum ${ }^{(26)}$.

Recognizing changes which occur in pregnancy and postpartum is fundamental in nursing to develop integral healthcare for women and their families, in which care centered on people and based on evidence is essential ${ }^{(26)}$.

The nursing team is present from prenatal to puerperium care, providing care to women and newborns, with a fundamental role in pain management and prevention of postpartum complications. Hence, permanent professional education and research are primordial for improving quality of assistance. Effective pain control may contribute to women's capabilities and well-being, fostering their return to daily activities.

The main limitation of this study is the fact that data collection was conducted in only one hospital, which limits generalization. For further studies, a multicenter research evaluating the impact of pharmacological and non-pharmacological interventions for pain in the puerperium is suggested.

\section{CONCLUSION}

The prevalence of pain was high in the postpartum period and the mean pain intensity was moderate, with intermittent frequency. The presence of pain was associated to cesarean birth, but pain intensity presented no relation with type of delivery or type of anesthesia.

The main pain sites were the abdominal and perineal areas. Pain significantly affected the mothers' activities during the postpartum period. Regarding pharmacological interventions for pain relief, all puerperal women reported being satisfied; however, pain was not resolved in all cases. The strategies for pain control in the postpartum period must be improved and non-pharmacological interventions must be employed more often by nurses. 
RESUMO

Objetivo: Identificar a prevalência de dor em puérperas, descrever as características e o impacto da dor no desempenho das atividades de vida diária e avaliar a satisfação com a analgesia recebida. Método: Estudo transversal que incluiu mulheres que deram à luz, avaliadas em até 72 horas pós-parto em hospital público de ensino da cidade de São Paulo. Foram avaliados dados clínicos e obstétricos, bem como presença, características e impacto da dor nas atividades diárias. Resultados: Participaram 128 mulheres. A prevalência de dor foi $36,7 \%$ no momento da entrevista e $54,6 \%$ nas últimas 24 horas. O principal local de dor foi a região abdominal (64,7\%) e a intensidade da dor foi moderada para 48,9\% das mulheres, com frequência intermitente em $58 \%$ dos casos. Houve associação significativa entre a presença de dor e o tipo de parto (cesariana; $\mathrm{p}=0,030$ ). Não prestar cuidado ao recém-nascido, tendo que se deslocar para outra unidade, aumentou a percepção de dor $(\mathrm{p}=0,038)$. Verificou-se impacto significativo da dor na capacidade de caminhar, comer, dormir, cuidar do bebê, evacuar, respirar fundo, amamentar e sentar-se. Conclusão: A dor foi frequente no período pós-parto e afetou significativamente as atividades maternas, indicando necessidade de se aprimorar o manejo da dor no puerpério.

\section{DESCRITORES}

Dor; Período Pós-Parto; Enfermagem Obstétrica; Enfermagem Materno-Infantil.

\section{RESUMEN}

Objetivo: Identificar la prevalencia del dolor en las puerperales, describir las características y el impacto del dolor en el desempeño de las actividades de la vida diaria y evaluar la satisfacción con la analgesia recibida. Método: Estudio transversal que incluyó a mujeres que dieron a luz, evaluadas hasta dentro de las 72 horas de posparto en un hospital público de enseñanza en la ciudad de São Paulo. Se evaluaron los datos clínicos y obstétricos, así como la presencia, las características y el impacto del dolor en las actividades cotidianas. Resultados: Participaron 128 mujeres. La prevalencia del dolor fue del 36,7\% en el momento de la entrevista y del 54,6\% en las 24 horas precedentes. El principal lugar de dolor era la región abdominal $(64,7 \%)$ y la intensidad del dolor fue moderada para el 48,9\% de las mujeres, con una frecuencia intermitente en el 58\% de los casos. Hubo una asociación significativa entre la presencia de dolor y el tipo de parto (cesáreo; $p=0,030$ ). El no cuidar al recién nacido por tener que trasladarse a otra unidad aumentaba la percepción del dolor $(\mathrm{p}=0,038)$. Hubo un impacto significativo del dolor en la capacidad de caminar, comer, dormir, cuidar del bebé, evacuar, respirar profundamente, amamantar y sentarse. Conclusión: El dolor era frecuente en el período de posparto y afectaba significativamente a las actividades de la madre, lo que indica la necesidad de mejorar el tratamiento del dolor en el puerperio.

\section{DESCRIPTORES}

Dolor; Periodo Posparto; Enfermería Obstétrica; Enfermería Maternoinfantil.

\section{REFERENCES}

1. Williams ACC, Craig KD. Updating the definition of pain. Pain. 2016;157:2420-3. doi: http://dx.doi.org/10.1097/j.pain.0000000000000613

2. Pereira TRC, Souza FG, Beleza ACS. Implications of pain in functional activities in immediate postpartum period according to the mode of delivery and parity: an observational study. Braz J Phys Ther. 2017;21(1):37-43. doi: http://dx.doi.org/10.1016/j.bjpt.2016.12.003

3. Barbosa EMG, Oliveira FDM, Guedes MVC, Monteiro ARM, Rodrigues DP, Silva LF, Fialho AVM. Cuidados de enfermagem a uma puérpera fundamentados na teoria do conforto. Rev Min Enferm. 2014;18(4):845-9. doi: 10.5935/1415-2762.20140062

4. Chang SR, Chen KH, Lee CN, Shyu MK, Lin MI, Lin WA. Relationships between perineal pain and postpartum depressive symptoms: a prospective cohort study. Int J Nurs Stud. 2016;59:68-78. doi: http://dx.doi.org/10.1016/j.ijnurstu.2016.02.012

5. Eisenach JC, Pan P, Smiley RM, Lavand'homme P, Landau R, Houle TT. Resolution of pain after childbirth. Anesthesiology. 2013;118(1):14351. doi: 10.1097/ALN.0b013e318278ccfd

6. Pan PH, Tonidandel AM, Aschenbrenner CA, Houle TT, Harris LC, Eisenach JC. Predicting acute pain after cesarean delivery using three simple questions. Anesthesiology. 2013;118(5):1170-9. doi: http://dx.doi.org/10.1097/ALN.0b013e31828e156f

7. Silva AMN, Santos LM, Cerqueira EAC, Carvalho ESS, Xavier ASG. Characterization of pain resulting from perineal trauma in women with vaginal delivery. Br J Pain. 2018;1(2):158-62. doi: http://dx.doi.org/105935/2595-0118.20180030

8. Zhang Y, Huang L, Ding Y, Shi Y, Chen J, McArthur A. Management of perineal pain among postpartum women in an obstetric and gynecological hospital in China: a best practice implementation project. JBI Database System Rev Implement Rep. 2017;15(1):165-77. doi: http://dx.doi.org/10.11124/JBISRIR-2016-003232

9. Lopes GA, Leister N, Riesco MLG. Perineal care and outcomes in a birth center. Texto Contexto Enferm. 2019;28:e20190168. doi: https:// doi.org/10.1590/1980-265x-tce-2018-0168

10. Mathias AERA, Pitangui ACR, Vasconcelos AMA, Silva SS, Rodrigues PS, Dias TG. Mensuração da dor perineal no pós-parto vaginal imediato. Rev Dor. 2015;16(4):267-71. doi: http://dx.doi.org/10.5935/1806-0013.20150054

11. Eshkevari L, Trout KK, Damore J. Management of postpartum pain. J Midwifery Womens Health. 2013;58(6):622-31. doi: http://dx.doi. org/10.1111/jmwh.12129

12. Cirico MOV, Shimoda GT, Oliveira RNG. Healthcare quality in brestfeeding implementation of the nipple trauma index. Rev Gaúcha Enferm. 2016;37(4):e60546. doi: http://dx.doi.org/10.1590/1983-1447.2016.04.60546

13. Jackson KT, Mantler T, O'Keefe-McCarthy S. Women's experience of breastfeeding-related pain. MCN Am J Matern Child Nurs. 2019;44(2):66-72. doi: 10.1097/NMC.0000000000000508

14. DeSantana JM, Perissinotti DM, Oliveira Junior JO, Correia LM, Oliveira CM, Fonseca PR. Definição de dor revisada após quatro décadas. Br J Pain. 2020;3(3):197-8. doi: https://doi.org/10.5935/2595-0118.20200191

15. Santos JO, Pacheco TS, Oliveira PS, Hino P, Gabrielloni MC, Barbieri M. Avaliação da dor no período puerperal: estudo comparativo entre os tipos de parto. J Health Sci Inst [Internet]. 2016 [citado 2018 out. 11];34(4):200-5. Disponível em: https://www.unip.br/presencial/ comunicacao/publicacoes/ics/edicoes/2016/04_out-dez/V34_n4_2016_p200a205.pdf

16. Manzo BF, Costa ACL, Silva MD, Jardim DMB, Costa LOD. Separação inevitável do binômio mãe-bebê no pós-parto imediato na perspectiva materna. Rev Bras Saúde Mater Infant. 2018;18(3):509-15. doi: http://dx.doi.org/10.1590/1806-93042018000300004 
17. Carvalho LDS, Pereira CMC. As reações psicológicas dos pais frente à hospitalização do bebê prematuro na UTI neonatal. Rev SBPH [Internet]. 2017 [citado 2018 set. 29];20(2):101-22. Disponível em: http://pepsic.bvsalud.org/scielo.php?script=sci_arttext\&pid=S1516$08582017000200007 \& \operatorname{lng}=$ pt

18. Jaafar SH, Ho JJ, Lee KS. Rooming-in for new mother and infant versus separate care for increasing the duration of breastfeeding. Cochrane Database Syst Rev. 2016;(8):CD006641. doi: http://dx.doi.org/10.1002/14651858.CD006641.pub3

19. Mascarello KC, Matijasevich A, Santos IS, Silveira MF. Early and late puerperal complications associated with the mode of delivery in a cohort in Brazil. Rev Bras Epidemiol. 2018;21:e180010. doi: http://dx.doi.org/10.1590/1980-549720180010

20. Fahey JO. Best practices in management of postpartum pain. J Perinat Neonat Nurs. 2017;31(2):126-36. doi: http://dx.doi.org/10.1097/ JPN.0000000000000241

21. Lehugeur D, Strapasson MR, Fronza E. Manejo não farmacológico de alívio da dor em partos assistidos por enfermeira obstétrica. Rev Enferm UFPE on line. 2017;11(12):4929-37. doi: https://doi.org/10.5205/1981-8963-v11i12a22487p4929-4937-2017

22. Dutra LRDV, Araújo AMPH, Micussi MTABC. Non-pharmacological therapies for postpartum analgesia: a systematic review. Braz J Pain 2019;2(1):72-80. doi: https://doi.org/10.5935/2595-0118.20190014

23. Âhlund S, Radestad I, Zwedberg S, Lindgren H. Perineal Pain the first year after childbirth and uptake of postpartum check-up - a Swedish cohort study. Midwifery. 2019;78:85-90. doi: https://doi.org/10.1016/j.midw.2019.08.004

24. Francisco AA, Oliveira SMJV, Leventhal LC, Bosco CS. Cryotherapy after childbirth: the lenght of apllication and changes in perineal temperature. Rev Esc Enferm USP 2013;47(3):555-61. doi: https://doi.org/101590/S0080-623420130000300005

25. East CE, Begg L, Henshall NE, Marchant PR, Wallace K. Local cooling for relieving pain from perineal trauma sustained during childbirth. Cochrane Database Syst Rev. 2012;(5):CD006304. doi: 10.1002/14651858.CD006304.pub3

26. Tsai SS, Wang HH, Chou FH. The effects of aromatherapy on postpartum women: a systematic review. J Nurs Res. 2020;28(3):e96. doi: https://doi.org/10.1097/jnr.0000000000000331

Conselho Nacional de Desenvolvimento Científico e Tecnológico (CNPq). Edital Universal, Process 421457/2016-3. Programa Unificado de Bolsas da Universidade de São Paulo. 